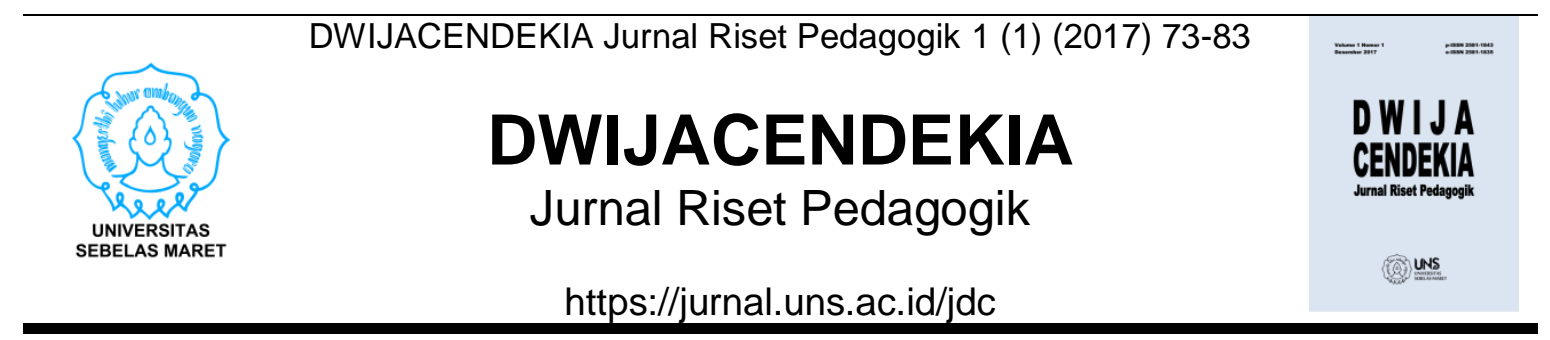

\title{
MANAJEMEN SUMBER DAYA MANUSIA UNTUK MENCAPAI PENDIDIKAN YANG BERKUALITAS DI SEKOLAH DASAR
}

\section{Rokhmaniyah}

Universitas Sebelas Maret

\section{Sejarah Artikel}

Diterima 20 Juli 2017

Disetujui 30 Juli 2017

Diterbitkan 1 Agustus 2017

\section{Kata Kunci}

manajemen, sumber daya manusia, kualitas

\begin{abstract}
Abstrak
Sumber daya yang ada di sekolah harus dikelola dengan benar untuk mewujudkan tujuan pendidikan nasional. Artikel ini mendeskripsikan hasil penelitian yang bertujuan untuk menganalisis manajemen sumber daya manusia di Sekolah Dasar Negeri 1 Kutosari Kebumen untuk mencapai pendidikan yang berkualitas. Penelitian ini menggunakan metode deskriptif kualitatif. Subjek penelitian ini ialah kepala sekolah, guru, dan tenaga administrasi sekolah. Sumber data penelitian adalah kepala sekolah, guru, tenaga administrasi sekolah, dan dokumen. Teknik pengumpulan data dilakukan dengan observasi, wawancara, dan studi dokumentasi. Untuk menjaga keabsahan data dilakukan dengan triangulasi teknik dan sumber. Analisis data dilakukan secara kualitatif. Kesimpulan hasil penelitian dinyatakan bahwa manajemen sumber daya manusia dalam penelitian ini dilakukan melalui langkahlangkah: rekruitmen, seleksi, penempatan, pengembangan, penilaian kinerja, pemberian imbalan, pemeliharaan hubungan baik, dan pemutusan hubungan kerja. Untuk mengoptimalkan sumber daya manusia dilakukan melalui pembinaan, pengawasan, bimbingan teknis, workshop, dan studi lanjut.
\end{abstract}

\section{Cara Mengutip}

Rokhmaniyah. (2017). Manajemen Sumber Daya Manusia untuk Mencapai Pendidikan yang Berkualitas di Sekolah Dasar. DWIJACENDEKIA Jurnal Riset Pedagogik, 1(1), 73-83.

Korespondensi Penulis: 


\section{PENDAHULUAN}

Sekolah merupakan suatu lembaga pendidikan formal yang menyelenggarakan kegiatan proses belajar mengajar sebagai upaya untuk tercapainya tujuan pendidikan. Penanggung jawab dalam proses belajar mengajar yang dilakukan di sekolah ditentukan pula bagaimana akhlak dan kinerja guru. Tinggi rendahnya mutu pendidikan banyak dipengaruhi oleh kualitas proses pembelajaran yang dilakukan oleh guru, karena guru secara langsung memberikan bimbingan dan bantuan kepada siswa dalam upaya mencapai tujuan pendidikan.

Mutu (quality) adalah suatu produk yang sesuai dengan harapan pengguna. Mutu merupakan suatu hal yang menyebabkan kepuasan terhadap pelanggan/pengguna. Pendidikan yang bermutu adalah pendidikan yang sesuai dengan standar dan memenuhi harapan masyarakat. Masyarakat sangat mengingikan hasil pendidikan dapat memenuhi kebutuhan pengguna. Untuk menciptakan pendidikan bermutu memerlukan proses pendidikan yang bermutu. Agar proses pendidikan bermutu maka harus dipenuhi beberapa komponen, salah satunya adalah sember daya manusia yang berkualitas.

Sumber daya manusia merupakan kekuatan terbesar dalam pengolahan seluruh sumber daya yang ada di sekolah. Sumber daya yang ada di sekolah harus dikelola dengan benar untuk mewujudkan tujuan pendidikan nasional. Manajemen sumber daya manusia adalah pengelolaan sumber daya manusia dari perekrutan sampai dengan pemberhentian yang dilakukan secara sistematis. Sumber daya manusia di sekolah ialah pendidik dan tenaga kependidikan, serta peserta didik. Sumber daya manusia di sekolah harus dikelola secara benar dan sistematis dari perekrutan sampai dengan pemberhentian.

Di Kabupaten Kebumen, memiliki lebih dari 1011 sekolah dasar, dengan sekolah dasar negeri berjumlah 861 dan sekolah dasar swasta berjumlah 150 (Dapodikdasmen Direktorat Pendidika Dasar dan Menengah, Kementerian Pendidikan dan Kebumdayaan, 2017). Dari 1011 sekolah dasar negeri maupun swasta terdapat satu sekolah dasar yang selalu menduduki peringkat ke-1 dalam lomba prestasi siswa, yaitu Sekolah Dasar Negeri 1 Kutosari Kebumen. Sekolah Dasar tersebut berstatus akreditasi $A$ dan berada di pusat kota Kebumen. Karena prestasinya yang selalu unggul maka sekolah ini banyak diminati oleh masyarakat untuk mendaftarkan anaknya bersekolah.

Salah satu kiat yang dilakukan Sekolah Dasar Negeri 1 Kutosari Kebumen dalam mempertahankan prestasi sekolahnya adalah dengan melakukan menajemen sumber daya manusia dengan baik, khususnya pengelolaan pendidik dan tenaga kependidikan. Oleh karena pentingnya peran manusia dalam kompetisi baik jangka pendek ataupun jangka panjang dalam agenda bisnis, suatu organisasi harus memiliki nilai lebih dibandingkan dengan organisasi lainnya. Organisasi yang berhasil dalam mempengaruhi pasar jika dapat menarik perhatian atas kelebihan yang dimiliki dalam berbagai hal dibandingkan dengan organisasi lain.

Suatu cara yang berkaitan dengan sumber daya manusia agar dapat menjadi sumber keungulan bersaing (competitive advantage) adalah melalui peningkatan modal manusia 
(human capital) untuk dapat mengenal dan beradaptasi dengan lingkungan yang selalu berubah. Suatu konsep yang menarik perhatian beberapa manajer akhir-akhir ini adalah organisasi pembelajar (learning organization), dimana setiap orang harus menambah pengetahuan dan kemampuannya agar dapat memberi hasil kerja yang lebih baik (Bangun, 2012).

Manajemen Sumber Daya Manusia (MSDM) yang dilaksanakan dengan baik akan memberikan kontribusi cukup besar dalam usaha mencapai sasaran organisasi atau perusahaan. Manajemen sumber daya manusia bertugas mempelajari dan mengembangkan cara-cara agar manusia dapat secara efektif diintegrasikan ke dalam berbagai organisasi guna mencapai tujuntujuannya. Tugas manajemen sumber daya manusia berkisar pada upaya mengelola unsur manusia dengan segala potensi yang dimiliki seefektif mungkin sehingga dapat diperoleh sumber daya manusia yang puas (satisfied) dan memuaskan (satisfactory) bagi organisasi ( Triyono, 2012).

Dari latar belakang itulah penulis ingin mencoba meneliti salah satu di Kabupaten Kebumen yang menurut pengamatan penulis perkembangannya cukup pesat, semua itu tidak terlepas dari apa yang dilakukan dalam mengelola sumber daya manusia yang ada sehingga masyarakat percaya kepada lembaga tersebut yaitu Sekolah Dasar Negeri 1 Kutosari Kebumen yang beralamat Jl. Piere Tendean No. 57 Desa Kutosari Kecamatan Kebumen Provinsi Jawa Tengah. Sekolah Dasar Negeri 1 Kutosari Kebumen berdiri pada 1 Januari 1953. Sekolah Dasar ini memiliki 192 peserta didik dengan jumlah rombongan belajar 6,7 guru, 1 tenaga administrasi sekolah (24 Agustus 2017). Dari wawancara dengan Ibu Hindun Sulastri selaku kepala sekolah, kemudian di buktikan dengan banyaknya piala di sekolah dalam berbagai ajang lomba, sekolah dasar ini banyak menjuarai berbagai ajang lomba POPDA dan OSN. Maka dari itu, penulis ingin mengetahui lebih dalam sekolah tersebut dengan membuat penelitian manajemen sumber daya manusia di sekolah tersebut dengan membuat judul "Manajemen Sumber Daya Manusia untuk Mencapai Pendidikan yang Berkualitas di Sekolah Dasar Negeri 1 Kutosari Kebumen.

Berdasarkan latar belakang di atas, maka dapat dirumusan masalah sebagai berikut. (1) Bagaimana manajemen sumber daya manusia di Sekolah Dasar Negeri 1 Kutosari Kebumen untuk mencapai pendidikan yang berkualitas?(2) Apakah manajemen sumber daya manusia di Sekolah Dasar Negeri 1 Kutosari Kebumen untuk mencapai pendidikan yang berkualitas dilaksanakan secara optimal? (3) Apa saja kendala dan solusi yang dihadapi dalam pengoptimalan manajemen sumber daya manusia di Sekolah Dasar Negeri 1 Kutosari Kebumen untuk mencapai pendidikan yang berkualitas? Adapun, tujuan penelitian ini sebagai berikut. (1) Menganalisi manajemen sumber daya manusia di Sekolah Dasar Negeri 1 Kutosari Kebumen untuk mencapai pendidikan yang berkualitas. (2) Mendeskripsikan tingkat optimalisasi manajemen sumber daya manusia di Sekolah Dasar Negeri 1 Kutosari Kebumen untuk mencapai pendidikan yang berkualitas. (3) Mengetahui kendala dan solusi yang dihadapi dalam pengoptimalan manajemen sumber 
daya manusia di Sekolah Dasar Negeri 1 Kutosari Kebumen untuk mencapai pendidikan yang berkualitas.

Sekolah yang berkualitas sangat didambakan masyarakat Indonesia sebagai tempat idaman bagi kaderkader terbaik bangsa untuk mengasah dan mengembangkan kemampuan secara maksimal dengan proses dan hasil yang memuaskan. Sekolah yang berkualitas adalah sekolah yang telah mampu mencapai standar pelayanan minimal dari Delapan Standar Nasional Pendidikan dan melaksankannya secara optimal. Manajemen diartikan sebagai "proses penggunaan sumber daya secara efektif untuk mencapai sasaran" (Berlian, 2015). Parker (Stoner dan Freeman, 2000) mengemukakan definisi manajemen yang berbeda dengan pendapat-pendapat di atas. Manajemen adalah seni untuk melaksanakan suatu pekerjaan melalui orang-orang. Hakikat manajemen menurut Hoyle (Bush \& Coleman, 2000) adalah sebagai berikut: "Management is a continous process through which members of an organization seek to co-ordinate their activities and utilize their resources in order to fulfil the various tasks of the organization as efficiently as possible. Manajemen adalah suatu proses yang terus menerus dilakukan oleh anggota orgaisasi dengan berusaha mengkoordinasikan kegiatannya dan memanfaatkan sumbernya untuk menyelesaikan berbagai tugas organisasi seefisien mungkin." Manajemen adalah suatu proses pencapaian tujuan organisasi melalui usaha orang-orang lain (Thoha, 2003).

Manajer mencapai tujuan organisasi dengan cara mengatur orang-orang lain untuk menjalankan tugas-tugas apa pun yang perlu, bukan dengan menjalankannya sendiri tugas-tugas tersebut ( Stoner, 1992). Robbins dan Coutler mengemukakan bahwa manajemen melibatkan aktivitasaktivitas koordinasi dan pengawasan terhadap pekerjaan orang lain, sehingga pekerjaan tersebut dapat diselesaikan secara efisien dan efektif (2010).

Manajemen dapat didefinisikan sebagai proses perencanaan, pengorganisasian, kepemimpinan dan pengendalian dari berbagai sumber daya organisasi untuk mencapai tujuan secara efektif dan efisien (Solihin, 2009). Empat fungsi manajemen menurut Terry dan Rue (2012) yaitu : planning (perencanaan), organizing (pengorganisasian), actuating (menggerakan), dan controlling (pengawasan).

Sumber Daya Manusia (SDM) atau human recources adalah usaha kerja atau jasa yang dapat diberikan dalam proses produksi. SDM menyangkut manusia yang mampu bekerja untuk memberikan jasa atau usaha kerja tersebut. SDM adalah orang-orang yang sedang kerja dan berusaha untuk proses produksi.

Manajemen sumber daya manusia dapat didefinisikan sebagai suatu proses perencanaan, pengorganisasian, penyusunan staf, penggerakan, dan pengawasan, terhadap pengadaan, pengembangan, pemberian kompensasi, pengintegrasian, pemeliharaan, dan pemisahan tenaga kerja untuk mencapai tujuan organisasi (Bangun, 2012). Umar mendefinisikan manajemen sumber daya manusia (MSDM) sebagai bagian dari manajemen keorganisasian yang memfokuskan diri pada unsur sumber daya manusia (Triyono, 2012. Sumber Daya Manusia membantu dalam 
mempekerjakan, mengevaluasi, penghargaan, melatih, memberikan konseling, mempromosikan dan memberhentikan karyawan (Dessler, 2007). Manajemen SDM yang efektif mengharuskan manajer menemukan cara terbaik dalam mengkaryakan orang-orang untuk mencapai tujuan perusahaan dan meningkatkan kinerja organisasi (Simamora, 2006)

Manajemen SDM menyangkut desain dan implementasi sistem perencanaan, penyususnan karyawan, pengembangan karyawan, pengelolaan karier, evaluasi kierja, kompensasi karyawan, dan hubungan ketenagakerjaan yang baik (Simamora, 2006). Aktivitas manajemen SDM dalam suatu lembaga organisasi meliputi: perencanaan SDM, rekrutmen, seleksi, penempatan, pelatihan dan pengembangan, penilaian kinerja, sistem imbalan/kompensasi, pemeliharaan hubungan kerja, dan pemutusan hubungan kerja (Siagian, 2015). Jadi, dapat disimpulkan bahwa manajemen sumber daya manusia adalah suatu proses perencanaan, pengorganisasian (penempatan), penggerakan dan pengawasan terhadap pengadaan (rekruitmen dan seleksi), pengembangan, pemberian kompensasi, pengintegrasian, pemeliharaan dan pemutusan hubungan kerja pegawai untuk mencapai tujuan organisasi yang efektif dan efisien. Sumber daya manusia dalam penelitian ini dibatasi pada pendidik dan tenaga kependidikan.

\section{METODE PENELITIAN}

Jenis penelitian dalam penelitian ini adalah penelitian lapangan (field research) yaitu pengumpulan data yang dilakukan secara langsung dilokasi penelitian. Penelitian ini menggunakan pendekatan deskriptif kualitatif. Penelitian deskriptif kualitatif ini bertujuan untuk memperoleh informasi mengenai keadaan yang ada. Penelitian deskriptif kualitatif dirancang untuk mengumpulkan informasi tentang keadaan-keadaan nyata yang sedang berlangsung (Mardalis,1999). Penulis akan meneliti segala sesuatu yang ada di objek penelitian utamanya dalam hal manajemen sumber daya manusianya. Dengan mencari dan mendapatkan sumber informasi tentang objek penelitian kemudian hasilnya akan dilaporkan sesuai dengan data dan fakta dari informan secara kualitatif.
Penelitian ini dilaksanakan di SD Negeri 1 Kutosari Kebumen Kabupaten Kebumen, Jawa Tengah. Lokasi ini dipilih karena SD Negeri 1 Kutosari Kebumen merupakan sekolah dasar yang yang yang terkenal banyak memperoleh prestasi baik akademik maupun nonakademik. Penelitian ini dilaksanakan tahun 2014. Subjek penelitian ini ialah Kepala SD Negei 1 Kutisari, Ibu Hindun Bestari, S.Ag., guru, dan karyawan tata usaha. Kepala sekolah. Kepala sekolah sebagai top leader di sekolahnya, sukses dan tidaknya sekolah tergantung dari seorang pemimpin dalam menjalankan roda pemerintahannya. Dalam hal ini kepala sekolah dijadikan subjek penelitian dalam manajemen sumber daya manusia di sekolah. Karena kepala sekolah yang mengatur segala 
peraturan yang ada di SD Negeri 1 Kutosari Kebumen mulai dari kegiatan pembelajaran sampai dengan yang lainnya. Kepala Tata Usaha merupakan tokoh yang mengatur segala urusan kaitannya dengan adminstrasi sekolah. Selain itu, peran Ka TU juga membantu kepala sekolah dalam hal mengelola sumber daya manusia yang ada di sekolah.
Sumber data penelitian ini adalah Kepala SD, Kepala TU, guru, dan dokumen. Teknik pengumpulan data dilakukan melalui wawancara dan studi dokumentasi. Untuk memeriksa keabsahan data digunakan teknik triangulasi teknik. Analisis data dalam penelitian ini dilakukan secara kualitatif mengacu ke pola Miles dan Huberman (Sugiono (2009), yaitu reduksi data, penyajian data, kesimpulan dan verifikasi

\section{PEMBAHASAN}

Manajemen Sumber daya manusia di Sekolah Dasar Negeri 1 Kutosari Kebumen untuk mencapai pendidikan yang berkualitas

Kegiatan manajemen sumber daya manusia dalam penelitian ini dilakukan melalui langkah-langkah: rekruitmen, seleksi, penempatan, pengembangan, penilaian kinerja, pemberian imbalan, pemeliharaan hubungan baik, dan pemutusan hubungan kerja.

\section{a. Rekruitmen pendidik dan tenaga kependidikan}

Hasil wawancara dinyatakan bahwa salah satu upaya yang dilakukan oleh SD Negeri 1 Kutosari Kebumen untuk menyampaikan informasi lowongan kerja yaitu dengan melaporkan ke dinas pendidikan tingkat kecamatan, dan kabuaten, serta disampaiakan kepada waraga sekolah terutama kepada para guru. Rekruitmen untuk GTT dipersyaratka kepada calon guru S1 PGSD mengacu pada kualifikasi minimal pendidik pada Permendiknas nomor 16 tahun 20016. Untuk tenaga kependidikan TAS diutamakan minimal lulusan SMA yang memiliki kemampuan mengoperasika komputer dan ber-IT. Adapun, penerimaan pendidik/guru dan tenaga kependidikan berstatus PNS dilakukan oleh pemerintah dan pihak sekolah tinggal menerima dan membina.

b. Seleksi pendidik dan tenaga kependidikan

Tahapan selanjutnya setelah rekrutmen adalah tahap seleksi. Seleksi yaitu dengan cara lamaran yang sudah masuk dipilih kembali sesuai jurusannya. Seleksi pertama adalah administrasi. Tahap selanjutnya dilakukan tes wawancara. Dari hasil seleksi administrasi dan tes wawancara kemudian diajukan ke rapat terbatas oleh kepala sekolah dengan beberapa guru senior. Calon pendidik dan tenaga kependidikan yang dinyatakan lulus untuk diterima diberi surat pemberitahuan penerimaan. Setelah itu, calon yang telah diterima dilakukan pembinaan oleh kepala sekolah dan pembimbingan oleh guru senior berkaitan dengan penguasaan empat kompetensi pendidik: pedagogik, kepribadian, sosial, 
dan profesional (Permendiknas nomor 16 tahun 2007). Untuk tenaga adminstrasi sekolah (TAS) dilakukan pembinaan dan pembimbingan oleh kepala sekolah untuk penguasaan kompetensi TAS (Permendiknas nomor 24 tahu 2008). Hal bertujuan agar kinerja pendidik dan tenaga kependidikan memiliki kinerja yang baik. Kondisi kinerja organisasi sekarang dan di masa depan dicerminkan dari kierja SDM yang tidak sekedar disebabkan dari perencanaan SDM, kegiatan rekruitmen, dan seleksi (Nawawi, 2001).

c. Penempatan pendidik dan tenaga kependidikan

Penempatan pendidik dan tenaga kependidikan merupakan langkah berikutnya setelah para pelamar dinyatakan lulus tes seleksi dan diterima di sekolah ini. Di dalam menempatkan pendidik dan tenaga kependidikan ini didasarkan pada kemampuan personal, pengalaman kerja, dan formasi yang harus diisi. Jika pendidik dan tenaga kependidikan yang diterima itu memiliki kemampuan lebih selain bidang yang mereka kerjakan, maka biasanya pendidik dan tenaga kependidikan tersebut ditempatkan dengan diberi tugas tambahan, misalnya sebagai pembimbing ektrakurikuler.

d. Pengembangan karier pendidik dan tenaga kependidikan

Program pengembangan untuk pendidik dan tenaga kependidikan dilakukan melaui kegiatan kolektif guru, workshop, bimbingan teknik, dan studi lanjut. Biaya tersebut ada yang dibebankan dari sekolah, dari pihak ketiga dan ada yang biaya sendiri.

\section{e. Penilaian kinerja pendidik dan tenaga kependidikan}

Penilaian kinerja dilakukan oleh kepala sekolah secara tertulis dan tidak tertulis. Secara tertulis, penilaian kinerja dilaksanakan setiap satu semester sekali yaitu berupa supervisi kelas. Sedangakan penilaian secara tidak tertulis biasanya dilakukan setiap waktu yang berupa pemantauan dan pengawasan baik dari kepala sekolah dan wali siswa. Penilaian kinerja wajib dilakukan karea untuk mengendalikan kinerja. Highperformance human resource management (HRM) practices also directly and negatively affect CSP concerns. HRM and innovation are important capabilities because they create and enhance other capabilities (Rothenberg, Hull, \& Tang, 2017).

\section{f. Sistem imbalan/kompensasi}

SD Negeri 1 Kutosari Kebumen juga menerapkan imbalan, perhitungan imbalan tidak seperti di tingkat SMP ataupun SMA yaitu melalui perhitungan jam mengajar, tetapi di SD ini diberikan setiap bulannya sama. Yang membedakan hanyalah tambahan selain menjadi guru misalnya membimbing lomba, menjadi pembina ekstrakurikuler, dan pramuka. Pemberian imbalan/honor mengajar kepada pendidik dan tenaga kependidikan, diberikan berdasarkan pertimbangan dengan komite sekolah.

\section{g. Pemeliharaan hubungan baik}

Pemeliharaan hubungan baik pendidik dan tenaga kependidikan tidak hanya berada dilingkungan sekolah. Akan tetapi, juga diterapkan kepada mitra sekolah, yang meliputi masyarakat dan wali murid di antaranya adalah: 
1) Mengadakan kegiatan silaturahim pada hari raya idul fitri dengan mengundang warga masyarakat sekitar dan orang tua atau wali siswa.

2) Pembagian sakat fitrah kepada para muzakki di wilayah sekolah dan sekiarnya dengan melibatkan pendidik dan tenaga kependidikan sebagai amil zakatnya

3) Mengadakan rapat dengan orang tua/wali siswa pada setiap awal semester.

4) Pada saat mengadakan perpisahan kelas 6 , selain orang tua atau wali siswa yang hadir, dari tokoh masyarakat sekiar juga diundang.

5) Kegiatan mujahadah persiapan UN dan persiapan penerimaan siswa baru juga mengundang orang tua atau wali siswa dan tokoh masyarakat.

Pemeliharaan hubungan baik utuk pengembangan motivasi sehingga menigkatkan kierja sesuai dengan penelitian yang dilakukan oleh Naryo (2011).

h. Pemutusan hubungan kerja dengan pendidik dan tenaga kependidikan

Aturan masa kerja di SD Negeri 1 Kutosari Kebumen khususnya untuk GTT dan pegawai non-PNS sebenarnya sama dengan yang guru/pegawai PNS. pemerintah yaitu sampai umur 60 tahun. Di sekolah ini, GTT dan pegawai nonPNS dilakukan pemutusan hubungan kerja karena kehendak sendiri atau karena sudah tidak dibutuhkan. Namun, selama ini, sekolah belum pernah melakukan pemutusan hubungan kerja karena kedua hal tersebut di atas. Pemutusan hubungan kerja yang pernah terjadi karena pensiun bagi yang PNS.

\section{Optimalisasi manajemen sumber daya manusia untuk mencapai pendidikan yang berkualitas}

Berdasarkan hasil wawancara dengan kepala sekolah, guru, dan tata usaha SD Negeri 1 Kutosari Kebumen, telah diperoleh hasil bahwa manajemen sumber daya manusia di sekolah ini telah dilakukan secara baik, tetapi belum optimal. Berdasarkan pemantauan dan pengamatan di lapangan, masih ada beberapa guru yang masih merangkap petugas administrasi. Selain itu, dibagian tata usaha seharusnya di seluruh bidang ada petugasnya tetapi sekolah ini masih belum terpenuhi, sehingga kinerja pendidik dan tenaga kependidikannya pun belum bisa maksimal.

Dalam upaya menjadi sekolah yang berkualitas, SD Negeri 1 Kutosari Kebumen perlu adanya kelengkapan sarana dan prasarana yang memadai, misalnya kantor guru tersendiri, ruang kepala sekolah sendiri, ruang TU sendiri, toilet guru dan siswa, pemenuhan alat-alat ruang kelas, LCD pada tiap ruang kelas, tempat ibadah, dan sarana olah raga.

Selain saran dan prasana, juga dilakukan peningkatan mutu dan kualitas pendidik dan tenaga kependidikan melalui bimbingan teknis, whorkshop, mengikutkan seminar, dan studi lanjut. Selanjutnya pembinaan pserta didik yang kompeten untuk mempersiapkan lomba-lomba seperti OSN, Mapsi, Lomba Cepat Tepat Pramuka dan lain-lain.

Dengan upaya hal tersebut di atas diharapkan mampu bersaing dengan sekolah-sekolah yang sudah lama 
berdiri dan semakin dikenal oleh masyarakat kebumen khususnya.

Kendala-kendala

dalam

melaksanakan manajemen sumber daya manusia

Dalam pelaksanaan manajemen sumber daya manusia di SD Negeri 1 Kutosari Kebumen ada beberapa kendala terkait dengan pendidik dan tenaga kependidikan di sekolah. Kendala-kendala yang dihadapi adalah masalah klasik, yakni situasi dan kondisi etos kerja pendidik dan tenaga kependidikan yang tidak konsekuen, terkadang disiplin dan terkadang tidak, ada yang semangat ada pula yang sedang menghadapi masalah keluarga atau pribadi. Masalah ini menghambat pelaksanaan manajemen sumber daya manusai di sekolah. Selain itu, guru tidak semuanya siap untuk hadir jam 07.00 pagi, sehingga hal ini menghambat aktivitas pembiasaan pada pagi hari di sekolah. Perihal administrasi pembelajaran, masih ada guru yang belum melaksankan tepat waktu.

Upaya kepala sekolah dalam mengatasi hal tersebut adalah kepala sekolah selalu memberikan motivasi kerja dan pembinaan kepada pendidik dan tenaga kependidikan secara rutin, misalnya setelah upacara bendera Senin pagi. Selain itu, kepala sekolah juga selalu mengingatkan kepada pendidik dan tenaga kependidikan yang melanggar aturan.

\section{SIMPULAN}

Berdasarkan hasil penelitian dan pembahasan di atas, maka dapat disimpulkan sebagai berikut.

a. Manajemen Sumber Daya Manusia di SD Negeri 1 Kutosari Kebumen sebagai berikut :

1) Perencanaan sumber daya manusia di SD Negeri 1 Kutosari Kebumen didasarkan pada situasi dan kondisi riil di sekolah.

2) Analisis jabatan dan kebutuhan tenaga kerja sudah dilakukan melaui persiapan, pengumpulan data dan klarifikasi data.

3) Kegiatan rekrutmen tenaga kerja disekolah ini sama halnya seperti rekrutmen di perusahaan yakni melalui lamaran kerja kemudian ada tes seleksi melalui wawancara.

4) Seleksi tenaga pendidik dan kependidikan (GTT dan pegawai non-PNS), yaitu dengan cara lamaran yang sudah masuk dipilih kembali sesuai jurusannya dalam hal ini diutamakan yang lulusan PGSD. Setelah itu dilakukan tes wawancara.

5) Penempatan pendidik dan tenaga kependidikan didasarkan pada kemampuan personal, pengalaman kerja, dan formasi. Jika pendidik dan tenaga kependidikan yang diterima itu memiliki kemampuan lebih, maka diberi tugas tambahan.

6) Pengembangan pendidik dan tenaga kependidikan dilakukan melalui kegiatan KKG (kelompok kerja guru), bimbingan teknis, workshop, dan studi lanjut.

7) Penilaian kinerja dilakukan secara tertulis melalui supervisi kelas, dan tidak tertulis melalui observasi, monitoring, dan pemantauan yang kemudian 
dituangkan dalam DP3 (Daftar Penilaian Prestasi Pegawai)

8) Sistem imbalan bagi GTT dan pegawai non-PNS diberikan pada setiap bulan.

9) Pemeliharaan hubungan pendidik dan tenaga kependidikan dengan dilakukan secara internal dan eksternak dengan mitra sekolah dan masyarakat.

10)Pemutusan hubungan kerja dengan pendidik dan tenaga kependidikan di sekolah ini dilakukan dengan dua model, yakni pemutusan hubungan kerja atas kehendak sendiri, meninggal, dan pemutusan hubungan kerja karena pension bagi yang PNS.

b. Upaya

mengoptimalkan manajemen sumber daya manusia di SD Negeri 1 Kutosari Kebumen untuk menjadi sekolah yang berkualitas di antaranya :

1) Adanya evaluasi bulanan di seluruh bidang yang ada di sekolah.
2) Adanya penilaian kinerja dan prestasi kerja

3) Adanya pelatihan dan studi lanjut bagi

4) Dipenuhinya saran dan prasarana sekolah

5) Adanya peningkatan semangat kerja pendidik dan tenaga kependidikan dengan cara sistem pembinaan dan pengawasan rutin.

6) Dilakukan koordinasi rutin dengan komite sekolah/orang tua/wali siswa.

c. Kendala-kendala yang dihadapi adalah yakni situasi dan kondisi etos kerja pendidik dan tenaga kependidikan yang kadang tidak konsekuen, terkadang disiplin dan terkadang tidak, ada yang semangat ada pula yang sedang menghadapi masalah keluarga atau pribadi. Solusi dilakukan dengan cara memberikan pembinaan, memberikan motivasi, diberikan teguran.

\section{DAFTAR PUSTAKA}

Bangun, W. (2012). Manajemen Sumber Daya Manusia. Jakarta :Erlangga.

Barlian, U.C. (2015). Manajemen Strategik Konsep dan Implementasi. Bandung: Klalifa Insan Cendekia Press.

Bush, T. \& Coleman, M. (2000). Leadhership and strategic management in education. London: Paul Chapman Publishing.
Dessler, G. (2007). Tt. Manajemen Sumber Daya Manusia jilid 2 ed.10. Jakarta : Indeks.

Naryo, W. (2011). Pasca Sarjana IAIN Syekh Nurjati Cirebon : Dampak Strategis Sumber Daya Manusia Terhadap Peningkatan Kinerja dan Mutu Pendidikan Di SD Islam Al Azhar 3 Cirebon.

Nawawi, H. (2001). Perencanaan SDM. Yogyakarta: Gadjah Mada University. 
Kemendiknas. (2007). Peraturan Menteri Pendidikan Nasional Nomor 16 Tahun 2007 tentang Kualifikasi dan Kompetensi Pendidik. Jakarta: Kemendiknas.

Kemendiknas. (2008). Peraturan Menteri Pendidikan Nasional Nomor 24 Tahun 2008 tentang Kualifikasi dan Kompetensi Tenaga Administrasi Sekolah. Jakarta: Kemendiknas.

Robbins, S. P. (2010). Manajemen edisi kesepuluh jilid 2. Jakarta: Erlangga.

Rothenberg, S., Hull, C. E., \& Tang, Z. (2017). The impact of human resource management on corporate social performance strengths and concerns. Business

Society, 56(3), 391-418.

Siagian, S.P. (2015). Manajemen Sumber Daya Manusia Edisi III. Jakarta : Bumi Aksara

Simamora, H. (2006). Manajemen Sumber Daya Manusia. Yogyakarta: STIE YKPN

Sugiyono. (2011). Metode Penelitian Kuantitatif, Kualitatif, Dan R\&D, Bandung, Alfabeta.

Solihin, I. (2009). Pengantar Manajemen. Jakarta : Erlangga.

Stoner, J. A.F dan R. Edward Freeman. (1992). Manajemen edisi Keempat Jilid 1. Jakarta : Intermedia.

Stoner, J.A.F \& Freeman, R.E. (2000). Management. New Jersey: Prentice-Hall International Editions.

Terry, G. R dan Leslie W. Rue. (2012). Dasar-dasar Manajemen. Jakarta: Bumi Aksara.

Triyono, A. (2012). Pardigma Baru Manajemen Sumber Daya Manusia. Jakarta: Suka Buku. 